Milica Mladenović ${ }^{1}$

Metropolitan University Belgrade,

Faculty of Management

Bojan Krstić ${ }^{2}$

University of Niš, Faculty of Economics
P. 29-36

SCIENTIFIC REVIEW PAPER

DOI: $10.5937 / E S D 2102029 M$

Received: February 10, 2021

Accepted: April 22, 2021

\title{
TRENDS AND STRATEGIC APPROACH TO ESTABLISHING WORK/LIFE BALANCE OF MANAGERS AND OTHER EMPLOYEES
}

\begin{abstract}
The purpose of the paper is presenting the most noticeable trends in establishing work/life balance of managers and other employees worldwide. Due to global changes, establishing work/life balance of employees is considered a strategic topic for human resource management (HRM). The research was conducted through a thorough analysis of various theoretical and empirical studies from the previous period, both domestically and abroad, with the aim of determining the extent to which companies have integrated employees' work/life balance programs into their HRM strategy and daily operations. Introducing training and the use of employees' work/life balance benefits leads to reduced stress and increased productivity, commitment and employee satisfaction. Consequently, this leads to improved company performance - reduced absenteeism and leaving of the company, lower recruiting and training costs, attracting and retaining top quality employees, as well as better company image. This way, employees' work/life balance programs provide benefits for both the employees and the company.
\end{abstract}

Key words: work/life balance, strategic approach, human resource management strategy

JEL classification: 015

\section{ТРЕНДОВИ И СТРАТЕШКИ ПРИСТУП УСКЛАЪИВАЫУ ПОСЛА И ПРИВАТНОГ ЖИВОТА МЕНАЏЕРА И ОСТАЛИХ ЗАПОСЛЕНИХ}

\section{Апстракт}

Циљ овог рада јесте представљање најзначајнијих трендова у усклађивању посла и приватног живота запослених и менаиера широм света. Услед глобалних промена, усклађивағе посла и приватног живота запослених сматра се стратешким питањем у управљаьу ьудским ресурсима. Истраживање је спроведено детаљном анализом многобројних теоријских и емпиријских студија реализованих у земљи и иностранству у претходном периоду, са циљем утврђивања у којој мери су предузећа интегрисала програме за усклађивање посла и приватног живота запослених у стратегију управљања људским ресурсима и своје свакодневно пословање. Увођење

\footnotetext{
${ }^{1}$ milica.mladenovic@metropolitan.ac.rs, ORCID ID 0000-0003-3210-0316

2 bojan.krstic@eknfak.ni.ac.rs, ORCID ID 0000-0003-4597-6819
} 
тренинга и коришћене погодности за усклађивање посла и приватног живота запослених доводи до смањењ а стреса и повећања продуктивности, посвећености и задовољства запослених. То последично доводи до побољшања перформанси предузећа - смањеног одсуствовања са посла и напуштања предузећа, нижих трошкова регрутовања и обуке, привлачења и задржавања најквалитетнијих запослених, те бољег имича предузећа. На тај начин програми за усклађиване посла и приватног живота запослених доносе погодности како за запослене тако и за предузеће.

Кључне речи: усклађеност посла и приватног живота, стратешки приступ, стратегија управљања људским ресурсима

\section{Introduction}

Establishing balance between work activities and private/home obligations represents work-life balance. (Friedman \& Greenhaus, 2000). Achieving work/life balance is a current issue, the importance of which will only grow in the future. Given the frequent difficulties in setting priorities between work and private commitments, various programs and benefits that companies offer can help establish employee work/ life balance. This allows managers and other employees to focus on work responsibilities when at work, and it also enables them to be efficient in performing home duties.

Therefore, the task of human resources sectors in companies is to provide superiors with guidelines for better employee management, with the purpose of improving their commitment and overall life satisfaction. The introduction of work/life balance training for employees and managers can lead to a significant improvement in the company's results, but also in the quality of life of its employees and managers (Postolov, Bardarova, Magdinčeva-Sopova, \& Ristovska, 2019). This training can also provide each individual employee and manager with necessary skills to establish work/life balance, in accordance with their needs and desires. This is very important since more work/life balance research has tackled the organizational and less the individual level so far (Krasulja, VasiljevićBlagojević \& Radojević, 2015).

This paper will address some of the most significant trends in establishing work/ life balance of managers and other employees. In addition, it will explain the importance of having a strategic approach when addressing work/life balance, with special emphasis on its individual aspects.

\section{Trends in establishing work/life balance}

The following trends can be observed in establishing work/life balance nowadays: elderly care, preoccupation with work obligations outside working hours, workaholism and overall life planning (Traynor, 1999).

A higher focus of employees and managers on elderly care represents a very noticeable trend nowadays. This claim is supported by predictions that by $2030,20 \%$ of Americans (around 70 million) will be older than 65, followed by the fact that the fastest growing segment of the elderly population is the population over the age of 85 , which has increased by an incredible $274 \%$ in the past 25 years (Society for Human Resource Management, 2002). Child care together with elderly care makes allocating time and 
attention to work and private obligations even harder. Consequently, it can be concluded that caring for the elderly will become a major issue for employees and managers in the following years.

Although not yet as widespread as child care programs, an increasing number of companies offer various elderly care programs to their employees and managers, such as providing contact information on elderly care services and even subsidized elderly care costs (Society for Human Resource Management, 2002). Some companies also offer programs that include assistance with child care costs together with elderly care. The task of human resource management is to clearly and transparently present the work/life benefits and programs offered by the company to its employees and managers, in order for them to become aware of them and to start using them.

Employees and managers are often preoccupied with work obligations outside working hours. It is very common that even when they spend time with their families, employees and managers are not able to completely relax and mentally focus on the present situation and environment, but are still at work in their minds, thinking about tomorrow's obligations and potential issues. Their family members have the impression that they are constantly thinking about work, which results in greater work and life dissatisfaction, more frequent conflicts between work and private obligations, a lower sense of happiness and more frequent burnouts at work (Ezzedeen \& Swiercz, 2002).

Research of employees in Serbia has shown that $78 \%$ of respondents think about tomorrow's work obligations at home and that $69 \%$ of respondents continue to perform work obligations at home, i.e. bring work home after working hours, resulting in chronic fatigue and dissatisfaction (Nosak \& Zubanov, 2013). This research also showed that the assumption of the dominant influence of personality characteristics, gender, age and family status of employees on their work/life balance was inadequate. According to this research, organizational culture created and supported by superiors is what dominantly influences work/life balance. This discovery provides a new basis for better understanding this important issue and creating more adequate work/life benefits according the employees and managers' needs.

Bonebright, Clay \& Ankenmann (2000) describe workaholics as a special group of employees and managers who have a high urge to work, high work engagement and a highly developed sense of responsibility and work commitment, differentiating only in the level or work enthusiasm. Research of these authors has shown work/life imbalance of workaholics, with a slight difference in the imbalance level - enthusiastic workaholics experienced higher life satisfaction and work/life balance compared to non-enthusiastic workaholics.

Overall life planning may be considered as a contemporary outlook on creating work/life balance programs that enables employees and managers to analyse and understand how these two aspects of their lives are interconnected. The goal of this approach is to encourage employees and managers to take a holistic view of their lives and to assess their relationships with other people, emotional stability, health, career and financial success. This enables employees and managers to evaluate available options to improve their work/life balance and develop their individual life plan, which this way becomes a goal for each individual, leading to an increase of energy, enthusiasm and productivity of employees and managers (Traynor, 1999).

Whether it is a new generation of employees increasingly valuing leisure activities, couples seeking to maintain a marriage while developing their careers, or single parents trying to earn a living and raise their children, human resources sectors in companies should create work/life balance programs for employees and managers in order to improve their productivity and reduce absenteeism. 


\section{Strategic approach to establishing work/life balance}

Human resource management has become a strategic topic for today's companies. Unlike the previous view of human resources as only one aspect of the company, modern companies understand that, due to the specific nature of the human factor, human resources should be managed in accordance with the strategy of the entire company. Strategic human resource management enables companies that have human resource management (HRM) policies and programs aligned with the company's mission, strategy, goals and culture to achieve better performance (Delery \& Doty, 1996).

Responsible human resource management, as an element of company's internal social responsibility, should be aimed at establishing work/life balance of its employees and managers (Stojanović-Aleksić \& Bošković, 2017). Within strategic management of employees and managers' work/life balance, companies can apply one of the two approaches - one-sided (systemic) or two-sided (individual) approach.

Until recently, companies applied a one-sided (systemic) approach to creating work/life balance programs, which involved defining policies, procedures and benefits of these programs for managers and other employees, such as: flexible working hours, part-time work, compressed work week, division of work, work from home, paid days off and holidays, child care, elderly care, stress management programs, sports, health and wellness programs (Bird, 2006).

While a one-sided (systemic) approach regards creating work/life balance programs for employees and managers as mostly a company issue, a two-sided (individual) approach raises both the question "what can the company do to enable establishing work/life balance of an individual employee or manager?", as well as the question "what can an individual employee or manager do to establish the best work/life balance for themselves?" (Bird, 2006). Disregarding the second question can often lead to not achieving the desired work/life balance of employees and managers in companies, which is why it is imperative that work/life balance programs include both the creation of a healthier work environment by the company and the behaviour change of employees and managers themselves.

Involvement of employees and managers is essential here because work/life balance represents a different set of elements for each individual employee or manager. For example, for some employees, overtime work creates value and balance in their lives, while for others it reduces productivity and job satisfaction (Bailyn, Fletcher \& Kolb, 1997). Also, the set of factors that establish work/life balance for every person can change in time, depending on whether they are starting their careers, preparing to leave their job or retire, as well as whether they are pursuing a career with no children or being a single parent.

Based on previous arguments, it can be concluded that the company alone cannot fully establish work/life balance of its employees and managers, but each individual employee and manager should discover and create a set of benefits that are most important to them in the present situation. It is necessary that the company help each individual employee and manager to develop skills that will enable them to not only understand the key factors that contribute to establishing work/life balance, but to also apply those skills both at work and in their private life (Byrne, 2005).

A two-sided (individual) approach to establishing work/life balance can be implemented by organizing training aimed at enabling employees and managers to better integrate their work and private lives in order to improve organizational efficiency (Bird, 2006). This training includes acquiring practical skills and tools that lead to increased work performance, satisfaction and work/life balance of employees and managers.

It has been observed that there is a great similarity between the skills needed for better interaction with family and friends and the skills necessary for better communication 
in team-oriented companies (Nosak \& Zubanov, 2013). Therefore, the skills of managing time, projects and interpersonal relationships, as well as the skills of providing more efficient services to consumers that are developed at work, are both transferred into the relationships of employees and managers with their family and friends, i.e. into their communication outside of work. The reverse is also true - the skills developed outside of work are transferred to the behaviour and communication of employees and managers at work. The ability of employees and managers to transfer the skills they have acquired in one role and apply them in the other role will lead to a significant improvement of the company's efficiency.

Training of the development of skills that employees and managers will use in their work and private lives should be part of the company's strategy due to its significance for everyone in the company. This training leads to greater retention, commitment and productivity, as well as to better behaviour and communication of employees and managers, which ultimately leads to greater satisfaction with both their work and private lives (Bird, 2006).

For the implementation of this training, it is necessary to have full support of the company's superiors, i.e. their participation in training, support and promotion. Superiors are actually the most common reason why employees and managers leave their companies, in most cases because of their disregard for private lives of employees and managers (Nosak \& Zubanov, 2013). Therefore, it would be adequate to start the training precisely with superiors, because the development of their skills will most certainly have the greatest and fastest impact on employee and management satisfaction. Afterwards, employees and managers should develop the same skills in order to improve their work efficiency and communication both at work and in their private lives, which will ultimately contribute to the improvement of their work/life balance (Bird, 2006).

A two-sided (individual) approach to creating work/life balance programs for employees and managers connects both the company's and employees' goals, while at the same time offering specific training to develop skills that will improve behaviour and quality of life of employees and managers, both at work and outside of work (Figure 1).

When creating a strategy for establishing work/life balance of employees and managers, the company should be guided by the effects that it wants to achieve by implementing the created work/life programs and benefits - these effects include better recruitment and selection, greater retention, productivity, commitment and work morale, as well as better quality of customer service, all of which will lead to a higher company revenue and profits (Lazăr, Osoian \& Raţiu, 2010).

On the other hand, employees and managers want to get a sense of achievement, satisfaction, pride in their work and the company, security, recognition, opportunity and better earning, which will ultimately lead to improved work/life balance and life quality (Lazăr, Osoian \& Raţiu, 2010). In order to achieve the desired effects, employees should, based on their life goals, needs and interests, but also the company's business goals, choose certain programs and benefits that they will use to create a positive work environment, in which it is a pleasure to work. Companies offer these programs in order to support and enable their employees and managers to lead a balanced life. However, each individual employee and manager needs to define and create their own work/life balance, which implies successful balancing between their work and private obligations. It is important that the company encourage each individual employee and manager to accurately and honestly define and express their goals and priorities in both work and private lives. 
Figure 1: Two-sided (individual) approach to creating work/life balance programs for employees and managers

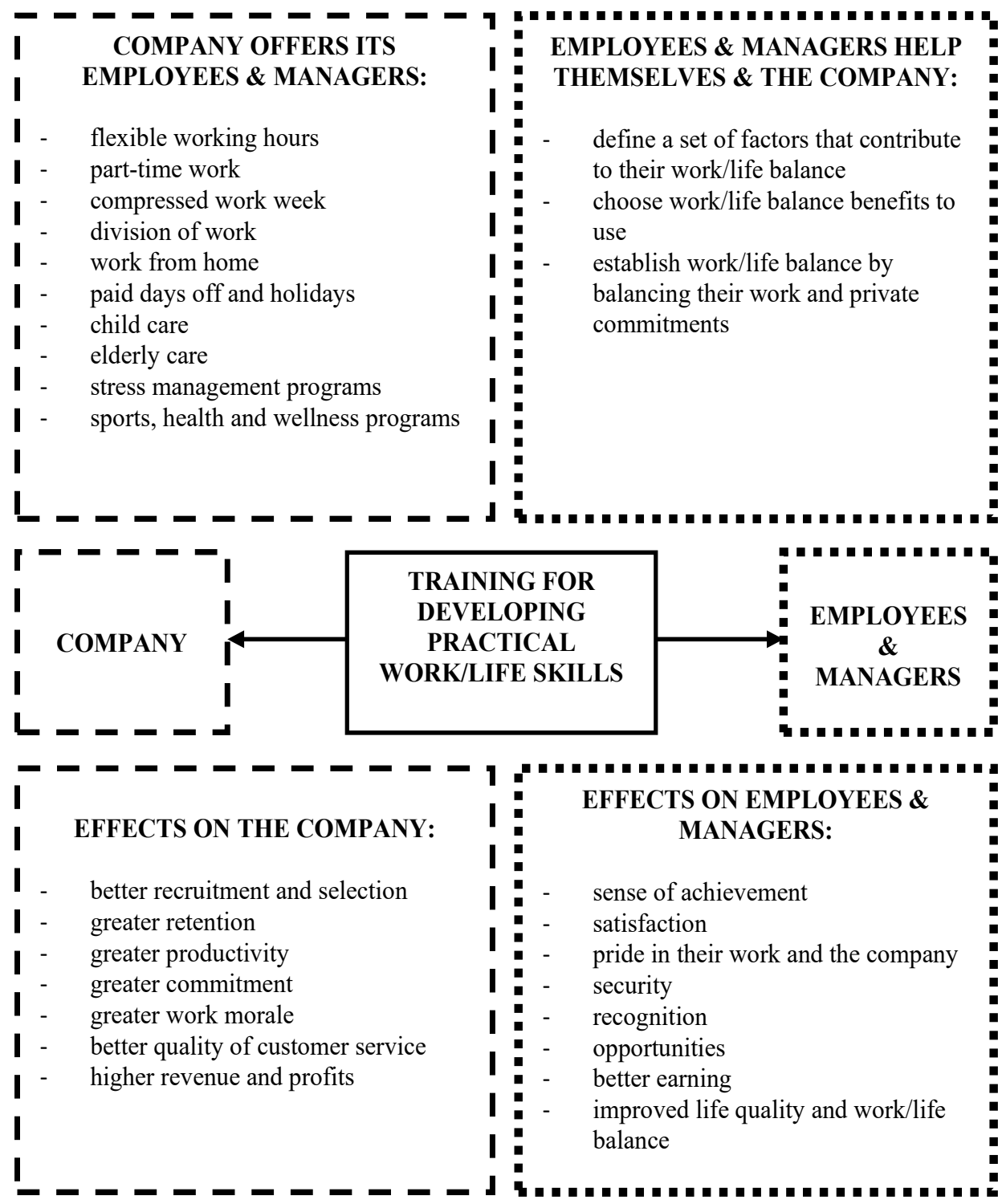

Source: Authors - based on: Byrne, U. (2005). Work/Life Balance: Why Are We Talking about it at all. Business Information Review, 22, 53-59. \& Lazăr, I., Osoian, C., \& Raţiu, P. (2010). The Role of Work/Life Balance Practices in Order to Improve Organizational Performance. European Research Studies, 13(1), 201-214.

The company provides training to develop practical skills that will enable employees and managers to think and behave in a more productive way, both at work and in their private lives. By developing these skills, employees and managers will achieve 
more and they will feel comfortable in their workplace, which will then be transferred into their private lives and it will contribute to increasing their life satisfaction and life quality (Bird, 2006).

\section{Conclusion}

Work/life balance includes a set of different factors for each individual employee and manager, and it can also change for each individual over time. Employees and managers should constantly search for a set of factors that help them achieve work/life balance in their present situation. These individual aspects are especially important in establishing a strategic approach to work/life balance. This balance implies the ability to perform most of the obligations and meet most of the expectations of employees and managers, both at work and in their private lives.

Establishing work/life balance of employees and managers while achieving the company's business goals requires training to develop practical skills that enable each individual employee and manager to establish their work/life balance. This paper has explained major trends in establishing work/life balance of employees and managers. This is a very important topic in strategic human resource management in companies nowadays. Companies have realized that the work/life balance of their employees provides benefits not only to them, but also to those companies, making it a strategic issue in today's business world (Mladenović, 2020). Therefore, establishing work/life balance of employees and managers has become one of the important topics in human resource management that requires strategic planning.

\section{References}

Bailyn, L., Fletcher, J. K., \& Kolb, D. (1997). Unexpected Connections: Considering Employees' Personal Lives Can Revitalize Your Business. Sloan Management Review, 38(4), 11-19.

Bird, J. (2006). Work/Life Balance - Doing It Right and Avoiding the Pitfalls. Employment Relations Today, 33(3), 21-30.

Bonebright, C., Clay, D., \& Ankenmann, D. (2000). The Relationship of Workaholism with Work/Life Conflict, Life Satisfaction and Purpose in Life. Journal of Counselling Psychology, 47, 469-477.

Byrne, U. (2005). Work/Life Balance: Why Are We Talking about It at all. Business Information Review, 22, 53-59.

Delery, J. E., \& Doty, D. H. (1996). Modes of Theorizing in Strategic Human Resource Management. Academy of Management Journal, 39, 830-835.

Ezzedeen, S. R., \& Swiercz, P. M. (2002). Rethinking Work/Life Balance: Development and Validation of the Cognitive Intrusion of Work Scale (CIWS). Dissertation Research Proposal, Proceedings of the Eastern Academy of Management Meeting.

Friedman, S. D., \& Greenhaus, J. H. (2000). Work and Family - Allies or enemies? What Happens when Business Professionals Confront Life Choices. New York: Oxford University Press. 
Krasulja, N., Vasiljević-Blagojević, M., \& Radojević, I. (2015). Working from Home as Alternative for Achieving Work-Life Balance. Ekonomika, 61(2), 131-142.

Lazăr, I., Osoian, C., \& Raţiu, P. (2010). The Role of Work/Life Balance Practices in Order to Improve Organizational Performance. European Research Studies, 13(1), 201-214.

Mladenović, M. (2020). Ravnoteža između poslovnog i privatnog života zaposlenih i menadžera - pogodnosti za balansiranje života i njihovi efekti. Ekonomski izazovi, 9(17), 67-79.

Nosak, T., \& Zubanov, V. (2013). Harmonizacija poslovnih i privatnih ciljeva zaposlenih. TIMS Acta, 7(2), 77-85.

Postolov, K., Bardarova, S., Magdinčeva-Sopova, M., \& Ristovska, A. (2019). Challenges in Managing Your Own Career Development, Ekonomski pogledi, 21(1), 17-34.

Society for Human Resource Management. (2002). Work/Life Balance. Workplace Visions, 4, 1-8.

Stojanović-Aleksić, V., \& Bošković, A. (2017). Društvena odgovornost preduzeća i etičko liderstvo. Economics of Sustainable Development, 1(2), 71-84.

Traynor, J. B. (1999). A New Frontier in Work/Life Benefits. Employee Benefits Journal, 24(4), 29-32. 